NBER WORKING PAPER SERIES

INCENTIVE EFFECTS OF WORKERS' COMPENSATION INSURANCE

Alan B. Krueger

Working Paper No. 3089

NATIONAL BUREAU OF ECONOMIC RESEARCH

1050 Massachusetts Avenue

Cambridge, MA 02138

August 1989

I am grateful to Joshua Angrist, Becky Blank, David Card, Pierre Chiappori, Bob Gibbons, Bruce Meyer, Walter Oi, Sherwin Rosen, Hans Werner Sinn, and an anonymous referee for helpful comments, and to seminar participants at the NBER, MIT, LSE, and Syracuse University for comments and suggestions on an earlier draft. I am also grateful to Angela Chang, Jillian Marcus, and Anne Piehl for research assistance. This paper was prepared for the NBER-LSE Conference on the "Future of the Welfare State." The computer program and data used in this research are available on request. This paper is part of NBER's research program in Labor Studies. Any opinions expressed are those of the author not those of the National Bureau of Economic Research. 
NBER Working Paper \#3089

August 1989

\title{
INCENTIVE EFFECTS OF WORKERS' COMPENSATION INSURANCE
}

\begin{abstract}
This paper uses Current Population Survey data on a large sample of workers to estimate the determinants of participation in state workers' compensation programs in the United States. The principal finding is that higher workers' compensation benefits are associated with greater participation in the workers' compensation program, after accounting for worker characteristics, state fixed effects, and other aspects of the workers' compensation law. Moreover, this result holds for both manufacturing and nonmanufacturing workers. Workers' compensation benefits, however, have an insignificant effect on program participation for the sample of women. Overall, a 10 increase in benefits is associated with a 6.7 increase in program participation. In addition, the results show that the waiting period that is required before benefit payments begin has a substantial negative effect on participation in the workers' compensation program. Finally, the parameters of the cross-sectional model are used to simulate the aggregate workers' compensation incidence rate from 1969 to 1987 . The growth in workers' compensation claims in the 1970 s appears to correspond reasonabiy well to the growth in real benefits that occurred during this time period.
\end{abstract}

\author{
Alan B. Krueger \\ Department of Economics and \\ Woodrow Wilson School \\ Princeton University \\ Princeton, NJ 08544
}


Horkers' compensation insurance was the first compulsory social insurance program in the United States, and the program remains the primary legal remedy for employees who are disabled by a work-related injury or illness. ' Workers' compensation laws require employers to purchase insurance or self-insure to provide a specified amount of cash benefits, medical care, and in some cases rehabilitation services to workers who are disabled on the job. Employer liability is independent of Eault. Each of the fifty states has its own workers' compensation law, and the state laws vary considerably with respect to benefit formulas and insurance provisions.

The economic rationale typically given in support of a government 'workers' compensation system is that for some reason the private labor market fails to provide the optimal level of safety and income protection in the event of work-related disabilities. The most rigorously developed empirical and theoretical hypothesis for the failure of the private market for safety and income security is that employees have imperfect information regarding the risks they face on the job, and therefore wage differentials do not ex ante fully compensate workers for their risk of injury. ${ }^{2}$ In the absence of fully compensating wage differentials for risk, employers might have an incentive to skimp on safety, and workers will not adequately insure against on-the-job risks because of informational asymmetries. In addition, the privace market may fail to provide adequate insurance to (risk averse) workers because of moral hazard problems and adverse selection. The goal of workers'

'The first workers' compensation law was passed by wisconsin in 1902 .

${ }^{2}$ Viscusi (1978) provides evidence that workers slowly learn of workplace hazards after they have been on the job. See Smith (1976) and the papers cited therein for evidence of insubstantial compensating wage differentials for less than fatal job risks. See Viscusi (1980), Rea (1981), and Carmichael (1986) for welfare analyses of workers' compensation insurance in the presence of imperfect information. 
compensation insurance is to ameliorate these potential market failures by insuring workers against work-related disabilities and by inducing employers to invest more resources in safety through experience-rated premiums.

In all social insurance programs there is poten: al for a moral hazard problem and other adverse incentives. In workers' compensation insurarice the potential moral hazard is particularly acute because, by providing workers with income protection in the event of workplace injuries, public policy may inadvertently encourage workers to take greater risks on the job and thus incur even more disabilities. Ideally, benefit levels are determined in a manner that takes account of any tradeoff between income security and moral hazard. Although theoretical treatments predict that an increase in imperfectly experience-rated benefits will lead workers to take more risks on the job, the theory gives no indication as to the magnitude or importance of this effect. In addition, workers have an incentive to "make up" injuries, or claim for injuries that occur off the job. Critics of workers' compensation insurance have argued that the current program should be scaled back or eliminated because the level of benefits encourages an excessive number of claims. $^{3}$ Ultimately, the issue of moral hazard in workers' compensation insurance is an empirical question. This paper contributes to the literature by presenting the first analysis of the determinants of participation in workers' compensation using micro-level data for a national sample of workers.

The institutional features of the workers' compensation system are described in the next section. The ways in which these institutional features affect employees' and employers' incentives to avoid occupational injuries and

${ }^{3}$ Chelius (1977), for example, provides a searching critique of the workers' compensation program based on moral hazard problems and proposes several directions for reform. 
illnesses are considered in section 2 . Section 3 presents a survey of previous empirical findings on the incentive effects of workers' compensation insurance. The previous research in this area primarily uses aggregate data on states and industries to estimate the relationship between workers' compensation clains rates (or injury rates) and benefit levels. Section 4 presents a new micro-level analysis of participation in the workers' compensation program that has the advantage of controlling for more detailed worker characteristics, of exploiting individual-level variation in benefits and behavior, and of being based explicitly on individual behavior. The principal finding is that higher workers' compensation benefits are associated with more injury claims for men but not for women. As shown in section 5 , the micro empirical model is relatively successful in accounting for the growth in the aggregate workers' compensation claims rate in the 1970 s.

\section{Description of the Workers' Compensation Insurance System}

The workers' compensation system in the U.S. consists of fifty autonomous state laws, a federal law covering federal employees, and a federal law covering longshoremen and harbor workers. The state laws operate without any restrictions or interference from the federal government. In 1985, the combined workers' compensation laws covered 87 of the workforce, and paid out a total of $\$ 22.5$ billion in benefits. ${ }^{4}$ In terms of total expenditures, workers' compensation insurance is larger than unemployment insurance, social security di_ability insurance, AFDC, or food stamps.

Workers' compensation insurance is a form of no-fault insurance in which employers must pay benefits to workers who are disabled on the job in exchange

${ }^{4}$ These figures are reported in Nelson (1988a). 
for limited liability and immunity from subsequent law suits. ${ }^{5}$ The states individually set their benefit levels and coverage requirements. Unlike most other social insurance programs in the U.S., eligibility for workers' compensation insurance begins the moment an employee enters covered employment. Typically, the employee has to prove by a preponderance of evidence that the injury or illness "arose out of and in the course of employment" to be awarded compensation. State laws unanimously cover all occupational diseases. Although employers are liable regardless of fault for workers' compensation claims, they may challenge whether the disability is actually work-related, and they may dispute the degree of the disability.

There are four main types of indemnity benefits in workers' compensation insurance. 6 First, "temporary total" benefits are paid to workers who are totally unable to work for a finite period of time. All workers' compensation claims are initially classified as temporary total cases and paid temporary total benefits; if the disability persists beyond the date of maximum medical improvement the case is reclassified as a permanent disability. About 70 of all claims are for temporary total disabilities. Second, if a worker remains totally disabled after reaching maximum medical improvement, he or she is eligible for "permanent total" benefits. In most states, permanent total and temporary total benefits are identical. Benefits equal a fraction (cypically

'In 47 states the workers' compensation law is compulsory. In the other three states (New Jersey, South Carolina and Texas) the workers' compensation law is elective by the employer, but almost all employers elect to be covered by the law to limit their potential liability in work-related accidents. See Hood and Hardy (1984) and Nackley (1987) for a summary of legal issues in workers' compensation insurance.

${ }^{6}$ In many states there is a fifth class of indemnity benefits known as temporary partial benefits. Since these cases account for a relatively small share of workers' compensation cases, they are not considered further. 
two-thirds) of the worker's pre-disability average weekly wage, subject to a maximum and minimum payment. The maximum allowable benefit varies substantially among states, and is often linked to the worker's number of dependents. In 1984, nearly 408 of workers earned a high-enough wage that if they incurred a cemporary total disability their benefic would be truncated by the maximum level in their state. ${ }^{7}$

Third, workers who suffer a disability that is partially disabling but is expected to last indefinitely qualify for "permanent partial" benefits. An employee who lost the use it a limb, for example, would receive permanent partial benefits. These benefits are typically determined on the basis of a schedule that links benefits to specific impairments. ${ }^{8}$ For example, an employee who loses the use of an arm in a work-related accident in New Jersey is enticled to a maximum benefit of $\$ 65,010$. Finally, dependents of workers who are killed on the job are paid survivors benefits.

Each state law requires a waiting period ranging from three to seven days before indemnity benefit payments begin. However, workers are compensated retroactively for the waiting period if their disability persists beyond a specified time period. Table 1 illustrates the inter-state variation in workers' compensation benefits, waiting perlods, and retroactive periods for ten states. In Ohio and Pennsylvania, low-wage earners would actually take home more than their salary by collecting workers' compensation insurance than by working. On the other hand, in Arizona, Indiana, and Mississippi the maximum benefit drastically restricts benefits for high-wage earners

7 Based on author's tabulation of the March 1985 Current Population Survey.

${ }^{8}$ Permanent partial disabilities that are not specified in the state disability schedules are compensated on a case-by-case basis. 
Table 1

Characteristics of Horkers' Compensation Insurance Laws in Ten States, 1985

\begin{tabular}{|c|c|c|c|c|}
\hline State & $\begin{array}{l}\text { Weekly Temp } \\
\text { Total Benefit } \\
\text { Pre-Tax Weekiy } \\
\$ 100.00\end{array}$ & $\begin{array}{l}\text { porary } \\
\text { Assuming } \\
\text { Wage of: } \\
\frac{\$ 00.00}{}\end{array}$ & $\begin{array}{l}\text { Waiting } \\
\text { Period (Days) }\end{array}$ & $\begin{array}{l}\text { Retroactive } \\
\text { Period Days }\end{array}$ \\
\hline Alabama & $\$ 80.00$ & $\$ 266.68$ & 3 & 21 \\
\hline Arizona & 66.67 & 154.00 & 7 & 14 \\
\hline Indiana & 66.67 & 166.00 & 7 & 21 \\
\hline Massachusetts & 66.07 & 266.88 & 5 & 6 \\
\hline Michigan & 67.82 & 231.94 & 7 & 14 \\
\hline Mississippi & 66.67 & 126.00 & 5 & 14 \\
\hline New Jersey & 72.00 & 269.00 & 7 & 8 \\
\hline Ohio & 118.00 & $288.00^{b}$ & 7 & 14 \\
\hline Pennsylvania & 112.00 & 268.68 & 7 & 14 \\
\hline Texas & 66.67 & 203.00 & 7 & 28 \\
\hline
\end{tabular}

Notes:

a. Benefit calculations assume the recipient has no dependents.

b. After 12 weeks the weekly benefit is reduced to $\$ 266.88$. 
There is a mixture of private, government, and self insurance in workers' compensation insurance. Most firms purchase their insurance from private insurance companies. Small employers are "manual rated," which means they are charged a premium on the basis of the historical safety experience of their industry. Larger firms are eligible for experience-rating which adjusts the manual race in accordance with the firm's own past safety record. Large firms also have the option to self-insure, which is equivalent to perfect experience-rating. Russel1 (1973) estimates that more than 808 of all employees work in firms that are not fully experience-rated. Although this figure may have changed somewhat in recent years, insurance premiums only partially reflect the firm's own injury experience for the majority of workers. Finally, it should be noted that unlike unemployment insurance, worker's compensation insurance rates vary by industry even for manually rated firms so there is little cross-industry subsidization.

\section{Safety Incentives in Workers' Compensation Insurance}

The workers' compensation system may have a variety of incentive effects for employers and employees. I begin by focusing on employee incentives in a static model that assumes that firms do not change the level of safety they provide or wages in response to the workers' compensation law. In addition, to abstract from problems of adverse selection, it is assumed that all workers are identical. 10 A worker will either have or not have a work-related insurance.

'More than 500 industry classifications are used in workers' compensation

${ }^{10}$ See Diamond (1977) for a discussion of variations among workers in their ability to avoid accidents. Rea (1981) and Ruser (1985) also provide models of moral hazard in workers' compensation insurance. 
disability over the period. Disabilities occur with probability $p$. For simplicity, it is assumed that all work-related injuries and illnesses qualify for a fixed workers' compensation insurance benefit, denoted B.

Workers choose over a continuum of non-negative effort levels to devote to safety, which is measured in terms of utility, e. This effort can be interpreted as time spent in accident-prevention activities, the unpleasantness of accident-prevention activities (e.g., wearing protective goggles), and resources devoted to accident-prevention. The function that relates the probability of incurring a compensable injury or illness to effort spent avoiding injuries is $\mathrm{P}=\mathrm{P}(\mathbf{e})$, where $\mathrm{P}^{\prime}(\mathbf{e})<0, \mathrm{P}^{\prime \prime}(\mathbf{e})>0$, and 0 $\leq p(e) \leq 1$. A moral hazard problem arises because $e$ is unobservable to employers and insurers and therefore can not be monitored.

It will be assumed that injuries occur in the beginning of employment, and that the only source of income available to injured workers is their workers' compensation benefit. 11 In addition, it will be assumed that any effort that workers devote to injury avoidance occurs before injuries arise, and that the disutility that workers derive from this effort is independent of whether they actually suffer an injury.

If a worker is disabled after providing $e$ units of safety effort, his utility is $V(B)-e$, and if the worker does not experience an injury his utility is given by $U(W) \cdot e$, where $U(\cdot)$ and $V(\cdot)$ are twice-differentiable, increasing, concave functions. Each worker sets the level of effort expended

${ }^{11}$ The assumption that injured workers do not receive wage income is consistent with the assumption that injuries occur in the beginning of the period. In addition, the restriction that injured workers do not receive benefits from private insurance arrangements may be justified either because $B$ is set above the optimal level of insurance, or because a private market for industrial accident insurance does not exist due to moral hazard problems. 
on safety to maximize expected utility, EU, given by

(1) $E U-[1-p(e)] U(W)+p(e) V(B)-e$.

Given a wage rate, the first order condition to this problem requires that for any positive level of $e$ :

(2) $P^{\prime}(e)[V(B)-U(W)]-1=0$.

By differentiating equation (2) and using the second order condition it can be shown that the effort an employee devotes to avoiding accidents will have the following properties:

(3) $\partial \mathrm{e} / \partial \mathrm{B}=\mathrm{p}^{\prime} \mathrm{V}^{\prime} / \mathrm{p}^{\prime \prime}(\mathrm{U}-\mathrm{V})<0$

(4) $\partial \mathrm{e} / \partial \mathrm{W}-\cdot \mathrm{P}^{\prime} \mathrm{U}^{\prime} / \mathrm{p}^{\prime \prime}(\mathrm{U}-\mathrm{V})>0$

where the arguments of the functions have been suppressed.

Since the probability a worker will incur a work-related injury depends inversely on the effort expended on safery activities, it follows that injuries will rise with benefits and decrease with the worker's wage. Intuitively, a higher benefit reduces the cost of incurring an injury and therefore leads employees to devote less effort to avoiding injuries. ${ }^{12}$ This result holds even though workers are better-off in the un-injured state than in the injured state.

${ }^{12}$ Sufficient conditions for these results to hold for a wider class of utility functions are: $\mathrm{U}_{\mathrm{We}} \geq 0$ and $\mathrm{V}_{\mathrm{Be}} \leq 0$. 
Employer Incentives

Employer responses to the workers' compensation system also need to be taken into account. The key factor influencing employer responses to workers' compensation insurance is the extent the program alters the firm's financial benefits from expending resources to reduce injuries. When employers' costs vary indirectly with their expenditures on safety, there is a "double moral hazard" problem in the sense that boti firms and workers take actions in response to the provision of insurance that affect the likelihood of work accidents (Lanoie, 1988).

Assume the probability that an employee suffers a work injury, $p(e, s)$, is a decreasing, convex function of the amount of resources that its firm expends on safety (s) and of the precautions the employee takes (e). Since firms' expenditures on safety typically precede employment and are relatively permanent (e.g., the design of the plant), this situation is plausibly thought of as a Stackelberg game where the firm is the leader and the employee is the follower. Firms will take their employees' reactions into accounc in determining the level of safety to provide. The employee reaction function is $e(B, W, s)-\operatorname{argmax}[1-p(e, s)] U(W)+p(e, s) V(B)-e$.

To reflect the imperfect nature of experience rating, let the firm's insurance premiums equal $c+\alpha p B$, where $c$ is the portion of costs that are not dependent on the firm's own accident experience and $0<\alpha<1$. Assuming that the firm's employment is fixed, it will maximize expected profits subject to the constraint that employees receive their reservation level of expected utility $(\overline{E U})$ :

$$
\max _{w, s} \pi=[1-\mathrm{p}(\mathrm{e}(\mathrm{B}, \mathrm{w}, \mathrm{s}), \mathrm{s})](\mathrm{R}-\mathrm{W})-\mathrm{s}-\mathrm{c}-\mathrm{p}(\mathrm{e}(\mathrm{B}, \mathrm{w}, \mathrm{s}), \mathrm{s}) \alpha \mathrm{B}
$$


s.t. $\overline{E U} \leq[1-p(e, s)] U(w)+p(e, s) V(B)-e$

where $R$ is revenue per worker.

In this situation, we can decompose the net effect of a change in benefits on injury rates as

(5) $d p / d B=P_{e} e_{B}+P_{s} \partial s / \partial B+P_{e} e_{s}^{\partial s / \partial B}+P_{e} e_{w}^{\partial w / \partial B}$.

It can be shown that $\mathrm{P}_{\mathbf{e}} \mathrm{e}_{B}>0$, but the remaining terms in (5) are of ambiguous sign because they depend on the cross derivative of $p(e, s)$. Without more structure on the technological safety function $p(e, s)$ it is impossible to predict the employer's response to changing benefits in the Stackelberg equilibrium.

\section{Reporting Incentives}

The moral hazard effect influences risk taking, but not all workers who are injured on the job will file for workers' compensation benefits. In many cases, an employee has some discretion over whether to ignore an injury and continue working, or to refrain from working and file an application for workers' compensation benefits. The decision to file an injury report will be influenced by the generosity of workers' compensation benefits.

Both moral hazard and reporting effects can be modelled by allowing the extent of injuries to vary. Formally, let the extent an employee is injured on the job be measured by a latent variable, $y$, with higher values of $y$ indicating more severe injuries. Suppose $y$ depends linearly on employee precautions, e, firm safety equipment, s, and a random component, $\varepsilon$, such that $\mathrm{y}=\varepsilon-\mathrm{e}-\mathrm{s}$. If $\mathrm{y}$ exceeds a certain threshold level, denoted $\mathrm{y}^{\star}$, the worker is regarded to have an injury. It is assumed that all injured employees who 
file for workers' compensation receive a benefit equal to $B$.

If an employee is injured but nonetheless continues working, he receives wage payments but bears further disutility for working while injured. The monetary value of the additional disutility an employee bears for continuing work instead of taking a leave from work to recuperate is $g(y)$, with $g^{\prime}(y)>0$. Some severe disabilities will automatically render an employee unable to work; for these types of disabilities $g(y)=\infty$.

An injured employee will choose to file a workers' compensation claim if $B>H-g(y)$, or $g(y)>W-B$. This inequality implies that for a given level of safety precautions, the incentive to file for workers' compensation benefits increases with benefits. Although many disabilities are so extreme that an employee has no choice but to stop working and file for benefits $(g(y)-\infty)$, in marginal cases employees will be encouraged to report injuries by generous benefits.

In the aggregate, the probability of filing a claim, $p$, is

(6) $\quad p=1-F\left(g^{-1}(W-B)+e+s\right)$

where $F(\cdot)$ is the cumulative distribution function of $\varepsilon$. From (6) it is clear that the level of benefits affects the workers' compensation recipiency rate through its effect on the amount of risk taking $(d(e+s) / d B)$, and through the incentive to file a claim for benefits given that an injury has occurred.

Finally, in practice there is imperfect state verification of injuries, and therefore some employees who are injured off the job, or who are not injured at all, may file workers' compensation claims if benefits are high 
enough. ${ }^{13}$ As the following quotation from Michelbacher and Nial (1925; p. 176) suggests, it has long been conjectured that workers may feign injuries or malinger in response to workers' compensation benefits.

\begin{abstract}
Malingering is not a new practice; it has existed from time immemorial. But it has become prominent under workmen's compensation laws and, therefore, has attracted unusual attention because of the large number of people affected and the opportunity offered by this legislation to procure benefits for injuries which may be feigned, exaggerated, deliberately aggravated or which may result from some form of hysteria or neurasthenia.
\end{abstract}

Without information on the origin and nature of work injuries, it is impossible to determine the extent to which a positive claims-benefits relationship results from an increase in true work accidents or from an increase in the rate of reporting injuries. A finding of no relationship between benefits and claims, however, would cast doubt on both explanations.

\title{
3. Previous Emplrical Research
}

Several empirical studies have attempted to quantify the extent to which industrial injuries are influenced by the workers' compensation system. ${ }^{14}$ The most common approach is to fit data on injury rates or workers' compensation claims rates to variables describing the key parameters of the state workers' compensation law. The past research has typically analyzed state-bymanufacturing-industry-level data or state-level data (see Chelius 1982 and

${ }^{13}$ Smith (1986), for example, provides circumstantial evidence that a small fraction of workers' compensation claims are for injuries that occurred in off-the-job activities. In particular, Smith finds a disproportionately high share of claims on Monday mornings for strains and sprains, but not for injuries that require immediate treatment, such as lacerations and fractures.

${ }^{14}$ See Ehrenberg (1988) for an excellent survey of the impact of workers' compensation insurance on workplace injuries and other labor market outcomes. 
2983, Butler 1983, Butler and Worral1 1983, Ruser 1985, and Bartel and Thomas 1985). Since these studies typically estimate nonlinear relationships with group averages for groups composed of heterogeneous individuals, they are best viewed as descriptive equations rather than as models based on disaggregated behavioral assumptions. 15

Anotrar potential source of bias in these studies of aggregate data is that the unit of observation may be inappropriate. For example, the industry level is likely to be an inappropriate unit of observation since the production technology in the various industries is likely to directly affect the frequency of work injuries.

Table 2 summarizes the results of six previous studies. The studies described in the table were selected because they provided sufficient information to make comparable calculations of the benefit and wage elasticities. ${ }^{16}$ All of these studies find that an increase in benefits is associated with an increase in the injury rate, and that an increase in the average wage is associated with a fall in the injury rate. There is considerable variation in the benefit and wage elasticities found in the various studies, however. The point estimates imply that the impact of a 10 s increase in benefits on work injuries would range from .68 to 7.18 .

In general, the studies that use the workers' compensation claims rate as the dependent variable find a larger effect of benefits than those that use the injury rate as the dependent variable. In addition, several studies find

${ }^{15}$ For example, since there is variability in benefits across individuals within states, the $10 \mathrm{~g}-\log$ specification does not aggregate from a sensible disaggregate model of individual behavior.

${ }^{16}$ I have chosen not to report estimates from other studies by these authors that use the same data but make minor changes in the specification. 


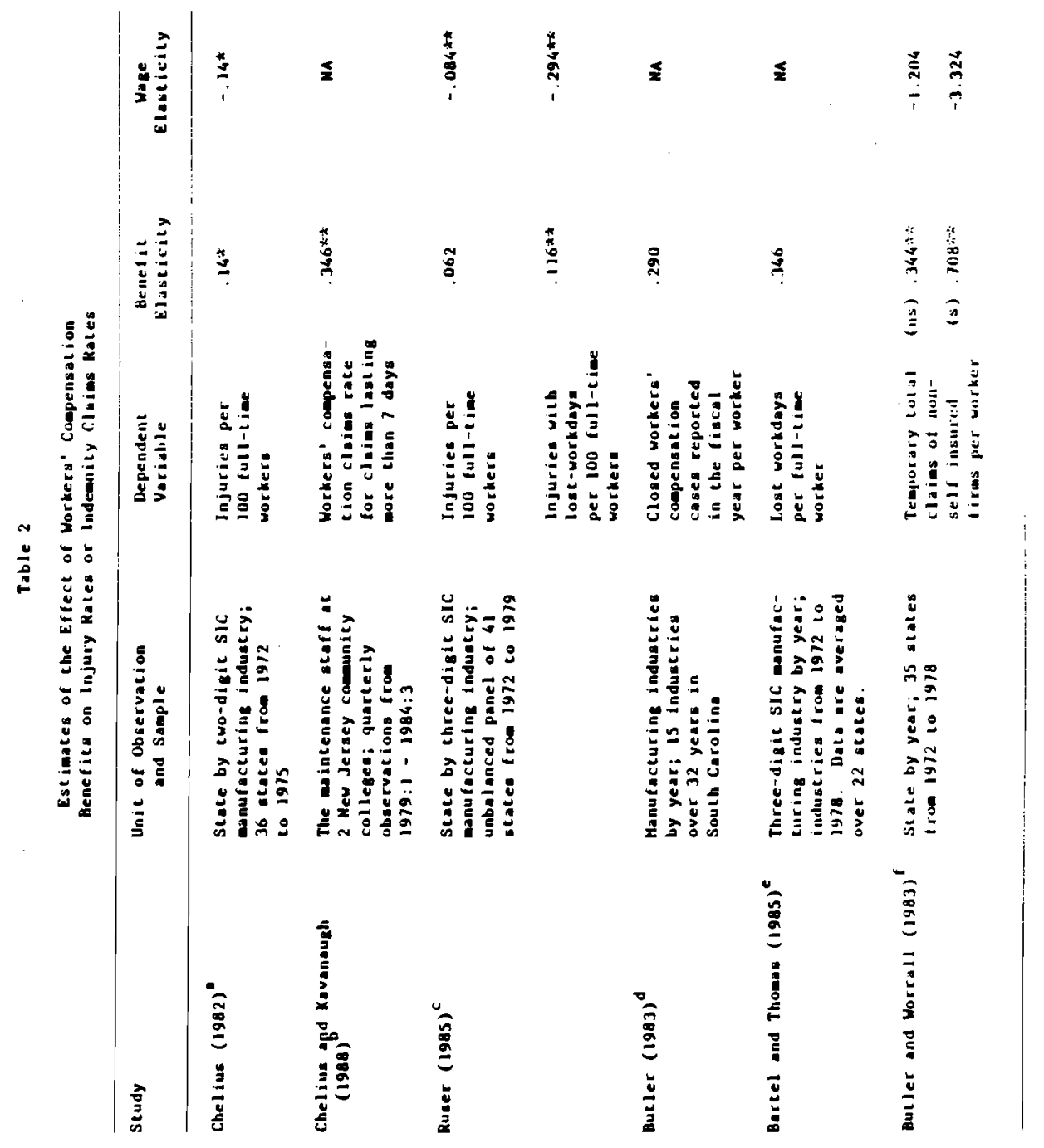




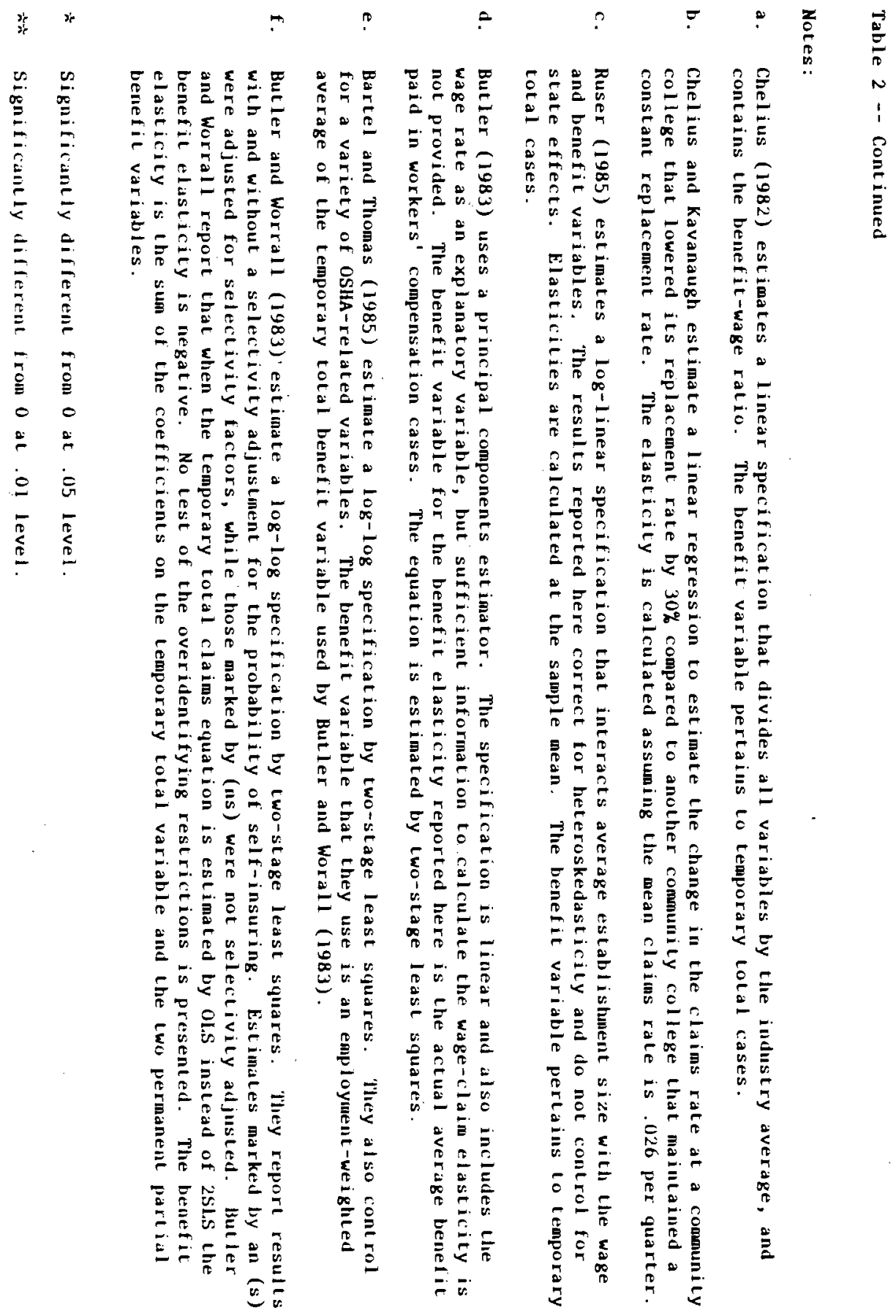


that a given change in benefits is associated with a greater proportionate increase in work fatalities than in temporary total cases and permanent partial cases (see Butler, 1983). These findings suggest that the relationship between workers' compensation claims and benefits reflects both genuine changes in employee behavior and increased reporting of claims for pre-existing disabilities or fraudulent claims.

The dispersion in the aggregate estimates of the impact of workers' compensation benefits and the sensitivity of the estimates to the outcome measure used suggest the need to examine more disaggregated data, as well as to use alternative approaches to estimate the incentive effects of the workers' compensation system. In addition, from the empirical work discussed so far one can not determine if a higher injury rate causes state legislatures to enact more generous benefits, or if higher benefits cause more injuries.

\section{A.Case Study}

In a case study of an unusual "natural experiment," Chelius and Kavanaugh (1988) provide evidence in favor of the view that higher benefits cause more workers' compensation claims, rather than vice versa. Their analysis arises from a common misinterpretation of a special New Jersey workers' compensation law that covers some employees of public colleges and universities. The law requires a higher workers' compensation benefit (1008 of wages) for faculiy and administrators than for the general public. Many colleges, however, mistakenly applied this law to their maintenance staff, who should have received the lower benefits ( 70 of wages) mandated by the general state law. One such community college discovered its error, and in 1981 abruptly imposed a 30 lower workers' compensation benefit for maintenance workers. 
Chelius and Kavanaugh compare the injury experience of the maintenance staff of the community college that reduced benefits to the injury experience of a similar community college that continued to pay high benefits throughout the same time period. They find that workers' compensation claims were significantly reduced at the community college that cut benefits relative to the "control" community college. Although other factors may have caused the relative change in injury rates in these colleges (e.g., both colleges switched to self-insurance in the sample period), one could clearly reject the hypothesis that injuries caused benefits in this example.

\section{The Relationship Between Benefits and Insurance Costs}

An alternative way to estimate the benefit-injury rate elasticity is to examine the relationship between benefits and the cost of workers' compensation insurance. A simple mocel of actuarially fair insurance implies that the cost of workers' compensation insurance per employee (C) equals the probability of a claim (p) times the average benefit or, $C$ p $B$.

If a worker's probability of filing an injury claim depends positively on the benefit rate because of moral hazard problems, then insurance costs would rise more than proportionally with benefits. 17 In particular, if the elasticity of the probability of filing a claim with respect to workers' compensation benefits is $\gamma$, then

$$
d \ln C=(1+\gamma) d \ln (B)
$$

17 If the loading factor in workers' compensation rates is proportional to the total amount of premiums written this implication still follows. 
Krueger and Burton (1987) use state-level data on workers' compensation costs and benefits from 1972 to 1983 to estimate equation (7). Their OLS estimate of $\gamma$ ranges from .083 to .218 , depending on the measure of insurance costs that is used as the dependent variable. When the benefit elasticity is estimated by instrumental variables (IV) to correct for measurement error in the benefit variable, the range of estimates of $\gamma$ increases to . 30 to . 35 . However, when state dumny variables are included to control for time-invariant aspects of the state workers' compensation system, both the OLS and IV estimates of $\gamma$ are small in magnitude and statistically insignificant. These results suggest that the benefit-claims elasticity may be smaller than those found by the studies summarized in Table 2 .

\section{Benefits and the Duration of Disability}

Another way workers' compensation can influence worker behavior is by affecting incentives to rehabilitate and return to work. By replacing a portion of foregone labor income during non-work spells, workers' compensation insurance may lead workers to delay their return to work and thus increase the duration of their disability. In a series of papers using data from Illinois, Butler and Worrall (1985), Worrall and Butler (1985) and Worrall, Butler, Borba, and Durbin (1987) estimate a variety of duration models to predict the length of stay on the workers' compensation program. Their sample exclusively contains males with temporary total lower-back injuries.

The principal finding of this work is that the duration of non-work spells increases with benefit levels and decreases with the worker's pre-disability wage rate. Butler and Worrall's (1985) "preferred" specification implies that a 108 increase in benefits would increase the 
duration of claims by $2 z$, or about one day.

Although the results of the duration models seem to imply that workers increase the duration of their disability in response to greater benefit levels, there are reasons to doubt this conclusion. First, identification of independent benefit and wage effects in a one state cross-sectional study is suspect. Linearly independent variations in benefits and wages are produced solely by non-linearities in the benefit formula when single state crosssectional data are used; and as discussed above, benefits are a negative, monotonic function of wages within a state. Consequenty, the effect of income replacement on non-work spells found in these studies may reflect the weaker attachment of low-wage workers to the labor force. Second, workers may be less likely to suffer a recurrence of their injury if they take more time to recuperate from their disability.

\section{Data and Emplzical Results}

To estimate the determinants of participation in the workers' compensation system, I have created a large micro-level data set by pooling together data on individuals from two successive matched March Current Population Surveys (CPS). ${ }^{18}$ Information is available on each individual for two consecutive years, either 1983 and 1984 , or 1984 and 1985 . The CPS contains a wealth of information on the personal characteristics and employment status of individuals, including retrospective information on earnings, weeks worked, and program participation in the calendar year preceding the survey. The fact that individuals are followed from one year to

${ }^{18}$ Although the CPS is not primarily a longitudinal data set, the rotation group design allows for up to half of the observations in a given sample to be matched to their previous year's records. 
the next is essential because it enables the identification of transitions into the workers' compensation insurance program: if a worker does not receive indemnity benefits from workers' compensation insurance in year $t-1$, but does in year $t$, it is assumed that the worker entered the workers' compensation insurance program sometime during year $t$.

Since benefics in year $t$ are determined by past wages, the weekly wage is calculated by dividing annual earnings in year $t-1$ (the year preceding the disability) by the number of weeks worked in year $t-1^{19}$ A potential temporary total workers' compensation benefit is calculated for each worker using information on the worker's pre-disability weekly wage, number of dependents, and the provisions of the workers' compensation law in the worker's state. ${ }^{20}$ Temporary total benefits are used as the benefit variable because all workers' compensation claims are initially classified as temporary total cases, and because temporary total cases represent more than 70 of cases in a given year. In addition, this may be an appropriate simplification because the formulas for permanent total benefits are virtually identical to those used for temporary total benefits, and because temporary total benefits

19

There are two advantages to using the previous year's weekly earnings to derive benefits. First, it is common for states to use the claimant's weekly wage in the 52 week period preceding the disability to calculate benefits. Second, weeks worked and earnings in year t-1 are not affected by injuries that occur in year $t$. It should also be noted that the weeks worked question in the CPS explicitly asks respondents to include paid sick leave as work, so in principle this procedure should yield a suitable weekly wage rate.

${ }^{20}$ The worker's compensation benefit equals the product of the weekly wage and the state mandated replacement rate unless this product exceeds the maximum benefit, in which case the worker is assigned the maximum benefit, or unless the product of the weekly wage and the replacement rate is less than the minimum payment in which case the worker is assigned the minimum benefit. Furthermore, if called for by the law, benefits were adjusted to reflect individuals' family characteristics. 'Information on state workers' compensation laws was derived from various issues of Analysis of Workers' Compensation Laws (Washington, D.C.: U.S. Chamber of Commerce, 1983-1984). 
are highly correlated with fatal and permanent partial benefits (Krueger and Burton, 1989, and Chelius, 1982).

Unlike labor income, workers' compensation benefits are not taxed.

Therefore, the real benefit of workers' compensation is a function of the tax rate. I derive an estimate of each worker's marginal tax rate by combining information on the worker's adjusted gross family income .e. family income net of transfer payments) with the average state, local and federal tax rate calculated by Feenberg and Rosen (1985). Tax rates are assigned on the basis of four income brackets. In addition, the social security payroll tax is taken into account for workers who earn less than the social security taxable maximum .

The sample is restricted to individuals age 18 to 65 who worked at least one week in year $t-1$ in a private, non-self-employed job, and earned at least the minimum wage. 21 Furthermore, individuals in Alaska, the District of Columbia, Iowa, and Michigan are eliminated from the sample because these jurisdictions calculate benefits on the basis of "spendable" earnings, not before-tax labor earnings. Finally, I have eliminated railroad workers, agricultural workers, longshoremen, harbor workers, seamen, and domestic employees because these individuals are likely to be covered by federal workers' compensation acts or not covered at all. The final sample contains 19,082 observations.

About 1.58 of the workers in the sample joined the workers' compensation insurance program during the year. This figure is in the range of estimates of workers' compensation cases per covered worker derived from administrative

${ }^{21}$ Individuals whose wage rate or workers' compensation recipiency status were allocated by the Census Bureau have been eliminated from the sample. 
records, which suggests that there is not a significant recall problem with workers' compensation recipiency in this data set. ${ }^{22}$

Table 3 presents descriptive statistics for the data set. On average individuals who receive workers' compensation payments have a slightly higher pre-disability weekly wage rate and are eligible for higher benefits than nonrecipients. This patzern might be explained by compensating differentials, which would suggest that jobs that entail a greater risk of injury would pay a higher wage to compensate for this additional risk, all else equal. I return to this issue below.

The table also indicates that workers who successfully file workers' compensation claims have different demographic and occupational characteristics than workers who do not receive income from the workers' compensation system. Workers' compensation recipients are more likely to be male, have less education, be married, work in blue collar jobs, and work in the manufacturing sector than non-recipients.

\section{Estimation}

To measure the impact of workers' compensation on the rate of industrial accidents and illnesses, one would ideally like to observe the amount of resources and effort that both employers and employees allocate to safety. Although such information is unavailable, the observed transitions into the workers' compensation program are an indicator of the latent employer and employee behavior. The reduced form estimate of the effect of benefits on the

22 The NCCI's Annual Statistical Bulletin, 1988 provides claims frequency data by state for full-time equivalent workers for 41 states. The correlation between the average workers' compensation claims rate estimated by CPS data and NCCI data for these states is .63 . 
Table 3

Sample Means by Workers' Compensation Recipiency ${ }^{a}$ (Standard Deviations in Parentheses)

\begin{tabular}{|c|c|c|c|}
\hline \multirow[b]{2}{*}{ Variable } & \multicolumn{3}{|c|}{ Sample } \\
\hline & Recipients & Non-Recipients ${ }^{c}$ & All Workers \\
\hline Weekly Benefit & $\begin{array}{l}\$ 199.06 \\
(67.05)\end{array}$ & $\begin{array}{l}\$ 185.87 \\
(76.54)\end{array}$ & $\begin{array}{l}\$ 186.07 \\
(76.42)\end{array}$ \\
\hline Weekly Wage & $\begin{array}{l}\$ 356.40 \\
(178.30)\end{array}$ & $\begin{array}{l}\$ 352.07 \\
(241.63)\end{array}$ & $\begin{array}{l}\$ 352.13 \\
(240.79)\end{array}$ \\
\hline Marginal Tax Rate & $\begin{array}{l}.36 \\
(.07)\end{array}$ & $\begin{array}{l}.37 \\
(.07)\end{array}$ & $\begin{array}{l}.37 \\
(.07)\end{array}$ \\
\hline $\begin{array}{l}\text { Waiting Period } \\
\text { (Days) }\end{array}$ & $\begin{array}{c}4.78 \\
(1.94)\end{array}$ & $\begin{array}{c}5.11 \\
(1.92)\end{array}$ & $\begin{array}{c}5.10 \\
(1.92)\end{array}$ \\
\hline $\begin{array}{l}\text { Retroactive Period } \\
\text { (Days) }\end{array}$ & $\begin{array}{l}14.69 \\
(7.73)\end{array}$ & $\begin{array}{l}15.30 \\
(7.71)\end{array}$ & $\begin{array}{l}15.29 \\
(7.71)\end{array}$ \\
\hline Male & $\begin{array}{l}.64 \\
(.48)\end{array}$ & $\begin{array}{l}.54 \\
(.50)\end{array}$ & $\begin{array}{l}.55 \\
(.50)\end{array}$ \\
\hline Age & $\begin{array}{l}37.76 \\
(11.69)\end{array}$ & $\begin{array}{c}37.83 \\
(12.41)\end{array}$ & $\begin{array}{c}37.83 \\
(12.40)\end{array}$ \\
\hline Education & $\begin{array}{l}11.81 \\
(2.38)\end{array}$ & $\begin{array}{l}12.70 \\
(2.54)\end{array}$ & $\begin{array}{l}12.69 \\
(2.54)\end{array}$ \\
\hline Black & $\begin{array}{c}.07 \\
(.25)\end{array}$ & $\begin{array}{c}.07 \\
(.25)\end{array}$ & $\begin{array}{c}.07 \\
(.25)\end{array}$ \\
\hline Hispanic and Other & $\begin{array}{l}.04 \\
(.19)\end{array}$ & $\begin{array}{l}.03 \\
(.17)\end{array}$ & $\begin{array}{l}.03 \\
(.17)\end{array}$ \\
\hline Never Married & $\begin{array}{l}.11 \\
(.31)\end{array}$ & $\begin{array}{l}.18 \\
(.39)\end{array}$ & $\begin{array}{l}.18 \\
(.39)\end{array}$ \\
\hline \multicolumn{4}{|l|}{ Oecupation } \\
\hline Manager & $\begin{array}{l}.03 \\
(.17)\end{array}$ & $\begin{array}{l}.11 \\
(.31)\end{array}$ & $(.11)$ \\
\hline Professional & $\begin{array}{l}.08 \\
(.27)\end{array}$ & $(.14$ & $\begin{array}{l}.13 \\
(.34)\end{array}$ \\
\hline Sales & $\begin{array}{l}.07 \\
(.25)\end{array}$ & $\begin{array}{l}.12 \\
(.32)\end{array}$ & $\begin{array}{l}.12 \\
(.32)\end{array}$ \\
\hline Clerical & $\begin{array}{l}.13 \\
(.33)\end{array}$ & $\begin{array}{l}.18 \\
(.39)\end{array}$ & $\begin{array}{l}.18 \\
(.39)\end{array}$ \\
\hline
\end{tabular}


Table 3 -- Continued

Sauple

Variable

Recipients ${ }^{b} \quad$ Non-Recipients ${ }^{c}$

A11 workers

Service

.09

(.29)

(.30)

10

(.30)

Grafe

.15

15

$(.41)$

(.36)

(.36)

Operative

.11

.12

(.39)

(.32)

(.32)

Transport Operative

Laborer

Industry

Mining

(.14)

.02

(.18)

(.14)

Construction

Manufacturing

Transportation

Communications

Public Utilities

Retail Trade

Wholesale Trade

Finance, Insurance

Service Ind.

Notes:

a. Data are from watched March CPS files, 1983-1984 and 1984-1985. See text for details.

b. This subsample of workers received casb income from workers compensation insurance in either 1983 or 1984 , but not in the preceding year.

c. This subsample of workers reported having no income from workers' compensation insurance in the sample period. 
workers' compensation claims rate can be thought of as reflecting the net influence of employer and employee incentives.

Table 4 presents coefficients from probit equations estimating the probability that an employee receives workers' compensation benefits in a given year. Results are reported for the full sample and for separate subsamples of men and women, and include varying sets of independent variables. The results show a statistically significant, positive relationship between benefits and program participation for men, but a small and extremely imprecise relationship for women. ${ }^{23}$ The elasticities reported on the bottom of the table indicate that a 108 increase in temporary total benefits will lead to a 4.63 to 6.7 increase in workers' compensation recipiency overal1. 24

When 46 state dummy variables are added to the equation, the benefitrecipiency elasticity increases to .71 . Identification in the within-state analysis is from variations in benefits across individuals (e.g., interpersonal variation in the maximum due to dependents), from changes in state

${ }^{23}$ Since, on average, women earn lower wages than men, women are less likely to have their benefit truncated by the statutory maximun. This reduces the variation in benefits for women. When the sample is restricted to full-time female workers, the effect of benefits becomes positive but is still statistically insignificant.

${ }^{24}$ For comparability, each elasticity, $\eta_{i}$, is evaluated at the overall sample mean as follows:

$$
\eta_{i}=\beta_{i} \phi(z) / \bar{p}
$$

where $\beta_{i}$ is the probit coefficient from a particular specification and sample, $\phi(\cdot)$ is the normal density function, $\delta(\cdot)$ is the cumulative normal distribution function, $z=\Phi^{-1}(\bar{p})$, and $\bar{p}$ is the overall sample mean workers' compensation participation rate. 
Tabla 6

The Deterninants of Transitions into Worters' Compenstion

Probit Eatientes with Asyeptotic Steadard Errora la Parentheses

\begin{tabular}{|c|c|c|c|c|c|c|c|c|c|}
\hline \multirow{3}{*}{$\begin{array}{l}\text { Iadepeadeat } \\
\text { Varzable }\end{array}$} & \multicolumn{9}{|c|}{ Sample } \\
\hline & \multicolumn{3}{|c|}{ All Workers } & \multicolumn{3}{|c|}{ Male Workers } & \multicolumn{3}{|c|}{ Fenele Horkers } \\
\hline & (1) & (2) & (3) & $\overline{(4)}$ & (5) & (6) & (7) & (i) & $(9)$ \\
\hline Loe Benefit & $\begin{array}{l}.264 \\
(.110)\end{array}$ & $\begin{array}{l}.180 \\
(.117)\end{array}$ & $\begin{array}{l}.294 \\
(.149)\end{array}$ & $\begin{array}{l}.283 \\
(.136)\end{array}$ & $\begin{array}{l}.170 \\
(.149)\end{array}$ & $(.396)$ & $\begin{array}{l}-.026 \\
(.210)\end{array}$ & $\begin{array}{l}-.062 \\
(.223)\end{array}$ & $\begin{array}{l}-.113 \\
(.267)\end{array}$ \\
\hline Log beekly wage & $\begin{array}{l}-.068 \\
(.079)\end{array}$ & $\begin{array}{l}.067 \\
(.091)\end{array}$ & $\begin{array}{l}.007 \\
(.107)\end{array}$ & $\begin{array}{l}-.150 \\
(.095)\end{array}$ & $\begin{array}{l}.026 \\
(.114)\end{array}$ & $\begin{array}{l}-.088 \\
(.143)\end{array}$ & $\begin{array}{l}.252 \\
(.160)\end{array}$ & $\begin{array}{l}.325 \\
(.173)\end{array}$ & $\begin{array}{l}.357 \\
.299\end{array}$ \\
\hline Yargianl Tax Race & $\begin{array}{r}-1.194 \\
(.353)\end{array}$ & $\begin{array}{l}-.731 \\
(.384)\end{array}$ & $\begin{array}{l}-.901 \\
(.428)\end{array}$ & $\begin{array}{r}-1.580 \\
(.493)\end{array}$ & $\begin{array}{r}-1.005 \\
(.547)\end{array}$ & $\begin{array}{l}-.928 \\
(.637)\end{array}$ & $\begin{array}{l}-.726 \\
(.508)\end{array}$ & $\begin{array}{l}-.529 \\
(.570)\end{array}$ & $\begin{array}{l}-931 \\
\therefore 2411\end{array}$ \\
\hline Waitias Period & $\begin{array}{l}-.038 \\
(.013)\end{array}$ & $\begin{array}{l}-.039 \\
(.016)\end{array}$ & $\cdots$ & $\begin{array}{l}-.029 \\
(.017)\end{array}$ & $\begin{array}{l}-.029 \\
(.018)\end{array}$ & -- & $\begin{array}{l}-.052 \\
(.210)\end{array}$ & $\begin{array}{l}-.061 \\
(.023)\end{array}$ & --- \\
\hline Retroactive Period & $\begin{array}{l}.0008 \\
(.003)\end{array}$ & $\begin{array}{l}.0008 \\
(.004)\end{array}$ & -- & $\begin{array}{l}-.002 \\
(.004)\end{array}$ & $\begin{array}{l}-.004 \\
(.005)\end{array}$ & $\cdots$ & $\begin{array}{l}.003 \\
(.005)\end{array}$ & $\begin{array}{l}.002 \\
(.006)\end{array}$ & $-\cdot$ \\
\hline yale & $\begin{array}{l}.107 \\
(.054)\end{array}$ & $\begin{array}{l}-.025 \\
(.067)\end{array}$ & $\begin{array}{l}-.031 \\
(.068)\end{array}$ & $\cdots$ & $\cdots$ & $\cdots$ & $\cdots$ & $\cdots$ & -- \\
\hline Age & $\cdots$ & $\begin{array}{l}-.005 \\
(.002)\end{array}$ & $\begin{array}{l}-.006 \\
(.002)\end{array}$ & $\cdots$ & $\begin{array}{l}-.005 \\
(.003)\end{array}$ & $\begin{array}{l}-.006 \\
(.003)\end{array}$ & $\cdots$ & $\begin{array}{l}-.004 \\
(.004)\end{array}$ & $\begin{array}{l}-.005 \\
(.004)\end{array}$ \\
\hline Education & $\cdots$ & $\begin{array}{l}-.031 \\
(.012)\end{array}$ & $\begin{array}{l}-.029 \\
(.012)\end{array}$ & -- & $\begin{array}{l}-.018 \\
(.015)\end{array}$ & $\begin{array}{l}-.018 \\
(.015)\end{array}$ & $\cdots$ & $\begin{array}{l}-.044 \\
(.021)\end{array}$ & $\begin{array}{l}-.039 \\
6.022:\end{array}$ \\
\hline Black & --- & $\begin{array}{l}-.049 \\
(.098)\end{array}$ & $\begin{array}{l}-.016 \\
(.103)\end{array}$ & $\cdots$ & $\begin{array}{l}-.084 \\
(.134)\end{array}$ & $\begin{array}{l}-.002 \\
(.142)\end{array}$ & -- & $\begin{array}{l}-.061 \\
(.151)\end{array}$ & $\begin{array}{l}-.006 \\
(.166)\end{array}$ \\
\hline Hispanic and Otber & -- & $\left(\begin{array}{l}136 \\
(139)\end{array}\right.$ & $\begin{array}{l}-.009 \\
(.158)\end{array}$ & $\cdots$ & $\begin{array}{l}.137 \\
(.192)\end{array}$ & $\begin{array}{l}.120 \\
(.228)\end{array}$ & -- & $\begin{array}{l}.158 \\
(.195)\end{array}$ & $\begin{array}{l}-.063 \\
(.230)\end{array}$ \\
\hline$y=-e r$ Marzied & $\cdots$ & $\begin{array}{l}-.218 \\
(.080)\end{array}$ & $\begin{array}{l}-.232 \\
(.082)\end{array}$ & --- & $\begin{array}{l}-.263 \\
(.108)\end{array}$ & $\begin{array}{l}-.267 \\
(.113)\end{array}$ & $\cdots$ & $\begin{array}{l}-.275 \\
(.133)\end{array}$ & $\begin{array}{l}-.346 \\
(.143)\end{array}$ \\
\hline Occupetion Dumies (8) & *o & Ye: & Yee & No & Yes & Yes & No & Yes & Yes \\
\hline $\begin{array}{l}\text { Two-Disit Iadustry } \\
\text { Dumies }(40)\end{array}$ & so & Yes & Yes & No & Te: & Ye: & No & Yes & Yes \\
\hline Stete Dumie* (46) & No & No & Yes & No & No & Yes: & No & No & Yes \\
\hline -2 Los likelibood & $2,959.5$ & $2,786.1$ & $2,709.2$ & $1,840.7$ & $1,681.8$ & $1,617.9$ & $1,107,0$ & $1,031.0$ & 946.0 \\
\hline Benefic Elaticieg ${ }^{c}$ & .665 & .654 & .741 & .713 & .428 & .993 & -.066 & -.156 & -.285 \\
\hline Wage Elesticity ${ }^{c}$ & -.171 & .169 & .018 & -.378 & .066 & -.222 & .635 & .819 & .900 \\
\hline
\end{tabular}

Notes:

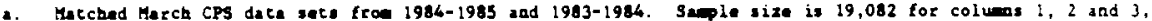
10,610 for colum 4,5 and 6 , and 8,672 for coluens 7 , Bad 9 . Eacb probit equation also iacludes an

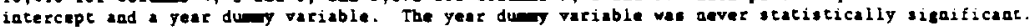

b. Benefit i. for e temporary totel diability. Ses toxt for further detaila.

c. For comprability, all elasticities are calculated at the wen of the vorkers' comeasation recipieacy rate (.0152) for the full samie. 
laws over the two years studied, and from nonlinearities in the benefit formulas. 25 The robustness of the elasticity to the inclusion of state dumy variables is important because state dummies control for unobserved, fixed aspects of the state workers' compensation program that might be correlated with benefits, such as whether the law is aggressively administered.

The technological constraints on employers and employees may affect the responsiveness of industrial infuries and diseases to the workers' compensation law. As a result, I estimate separate auxiliary probit equations for manufacturing and nonmanufacturing workers. The elasticity of workers' compensation recipiency with respect to benefits is .593 for manufacturing workers and .409 for nommanuacturing workers, where the elasticities are derived by evaluating the probit coefficients at the mean workers' compensation rate for the full sample. ${ }^{26}$ The difference between these elasticities, however, is not statistically significant.

The model in section 2 predicts that the incentive to file a workers' compensation claim decreases with the after tax wage rate because the opportunity cost of being on the workers' compensation program increases with wages. 27 The direction of the effect of wages on workers' compensation recipiency found in Table 4 fluctuates depending on the sample and the

${ }^{25}$ For example, between 1983 and 1984 the real statutory maximum benefit increased by $57 \%$ in New Hampsire, $14 \%$ in New York, and 108 in California. Since the waiting period and retroactive period did not vary within states in these years, they are excluded from the within-state analysis.

${ }^{26}$ These equations control for all the variables in column (2) of Table 4 except for industry and occupation dummies. They are available on request.

27 The marginal tax rate and the weekly wage are allowed to have different coefficients. The after tax wage rate equals $(1-r) w$, where $r$ is the marginal tax rate and $W$ is the weekly wage. Since the specification enters benefits and wages in logs, $\tau \approx-\ln (1-\tau)$, and $\ln W$ are entered separately. 
specification, and the tax variable has a negative and highly statistically significant effect. One explanation for these findings is that unobserved risk of injury on the job leads to both higher wages and a higher "nrkers' compensation recipiency rate. However, when several occupation dumy variables and two-digit industry dummy variables are added to the equation to control for differences in working conditions the coefficient on the wage rate becomes larger, which suggests it is not an artifact of inherent differences in job risk across occupations and industries.

In addition, since both the marginal tax rate and the weekly benefit are complicated nonlinear functions of past wages, it is possible that the tax rate is confounding some of the effect of benefits. Other coefficients are qualitatively unchanged, however, when the tax variable is dropped from the equation.

Two other variables in the equations reflect components of the workers' compensation system. A longer waiting period tends to reduce the probability that a worker will receive workers' compensation benefits. The coefficient estimate in column (1) implies that if the waiting period were increased from three to seven days, the workers' compensation recipiency rate would fall by 38.78. This result may represent a behavioral response by workers to a larger "deductible," or a non-behavioral truncation of disabilities that do not persist beyond the waiting period.

Since most firms provide at least partial "sick pay" to employees during the waiting period, the waiting period is unlikely to serve as an important deductible for many workers (U.S. Chamber of Commerce, 1986). In addition, administrative data from the state of Minnesota, which has a three day waiting period, indicate that 29.38 of workers' compensation recipients leave the 
program within seven days. These findings suggest that the estimated effect of the waiting period is largely a result of the high density of short injury spells that fail to qualify for workers' compensation.

In contrast to the waiting period, the retroactive period has a statistically insignificant and trivial effect on the probability of receiving workers' compensation benefits.

Several demographic variables are also included in the probit equations. The results in column (1) find that males are more likely to receive workers' compensation payments than females. The second column shows, however, that the differential between men and women disappears when industry, occupation, and other demographic factors are held constant. Married men and married women are more likely to receive workers' compensation benefits than single workers of the same sex.

Finally, as one might expect, the equations indicate that less-educated workers and younger workers are comparatively more likely to receive workers' compensation benefits. Root (1981) and Mitchell (1988) similarly find that the frequency of work accidents decreases with age.

\section{Explaining the Time-Series Pattern of Workers' Compensation Incidence}

To explore whether the estimated effect of benefits on program participation is of plausible economic magnitude, in this section I evaluate the ability of the cross-sectional model to predict the recent time-series pattern of workers' compensation incidence rates. The ability to predict time-series trends on the basis of parameters estimated from a disaggregate cross-sectional model is a difficult test of the underlying cross-sectional model because variables that are constant at a point in time may vary over time. In the present application, only the workers' compensation benefit 
level is allowed to vary over time, so the predicted incidence rate does not reflect other relevant variables that may have changed in this period.

A time-series analysis covering the $1970 \mathrm{~s}$ is of particular interest because in 1972 the National Commission on State Workmen's Compensation Laws issued a report that conditionally endorsed federal minimum standards for state workers' compensation laws uniess the states voluntarily increased their benefits to comply with its proposed standards. Perhaps in response to the threat of federal standards, many states dramatically increased the real value of their benefits in the mid-1970s. The success of the National Commission in increasing benefits in some states provides significant time-series variation in the benefit level.

Another reason for performing a time-series simulation is that the estimated cross-sectional effect of benefits would be biased upwards if individuals' workers' compensation benefits were positively correlated with other social insurance benefits that they might qualify for, and if workers frequently participate in multiple social insurance programs. ${ }^{28}$ Unless other social insurance benefits followed the same time-series pattern as workers' compensation benefits, however, the time-series prediction will diverge from the actual incidence rate. Thus, the time-series comparison provides a check on the validity of the cross-sectional estimates.

Since a nationally representative time-series of workers' compensation incidence rates does not exist for the United States, I have estimated one from 1969 to 1987 using each year's March CPS. Efforts were taken to make the

${ }^{28}$ Since the vast majority of workers' compensation recipients have short, temporary disabilities, there may be little overlap between workers' compensation and other social insurance programs, such as social security disability insurance. 
series comparable over time. The derivation of this series is detailed in the Appendix.

Using the same methods used to impute benefits for the cross-sectional analysis, benefits were imputed for each worker in each year from 1969 to 1987 based on the prevaiing state law. Specifically, each worker's 1983 weekly wage in the CPS was adjusted for economy-wide annual wage growth, and the relevant temporary total benefit formula was applied to the micro data to derive a potential benefit for every worker in the sample in every year. Bt...fits were then converted to current dollars.

A predicted (or simulated) incidence rate, $\hat{p}_{t}$, was calculated from the probit equation with micro data according to

$$
\hat{p}_{t}=\frac{1}{\bar{N}} \sum_{i}\left[\Phi\left(\hat{\alpha}+\hat{\beta B} B_{i t}+\mathrm{X}_{i} \hat{\gamma}\right)\right] \quad \begin{aligned}
& t=1969, \ldots, 1987 \\
& i=1, \ldots, N
\end{aligned}
$$

where $\Phi$ is the normal cumulative distribution function, $B_{i t}$ is the $\log$ of the simulated real workers' compensation benefit for worker $i$ in year $t, x_{i}$ is a vector of explanatory variables that is assumed constant over time (but not across individuals), $\hat{\beta}$ and $\hat{\gamma}$ are the parameter vectors estimated in column 1 of Table 4 , and $\hat{\alpha}$ is a constant normalized so that the predicted incidence rate equals the actual incidence rate in the first year of the sample, 1969.29 In each year, the vector of explanatory variables $(X)$ is set equal to the values for the sample in 1983 .

Figure 1 displays the actual incidence rate and a prediction of the incidence rate each year based on the cross-sectional model for the years 1969-1987. As other researchers have conjectured on the basis of incomplete

${ }^{29}$ The predicted incidence rate is based on a sample of 9,343 observations. 


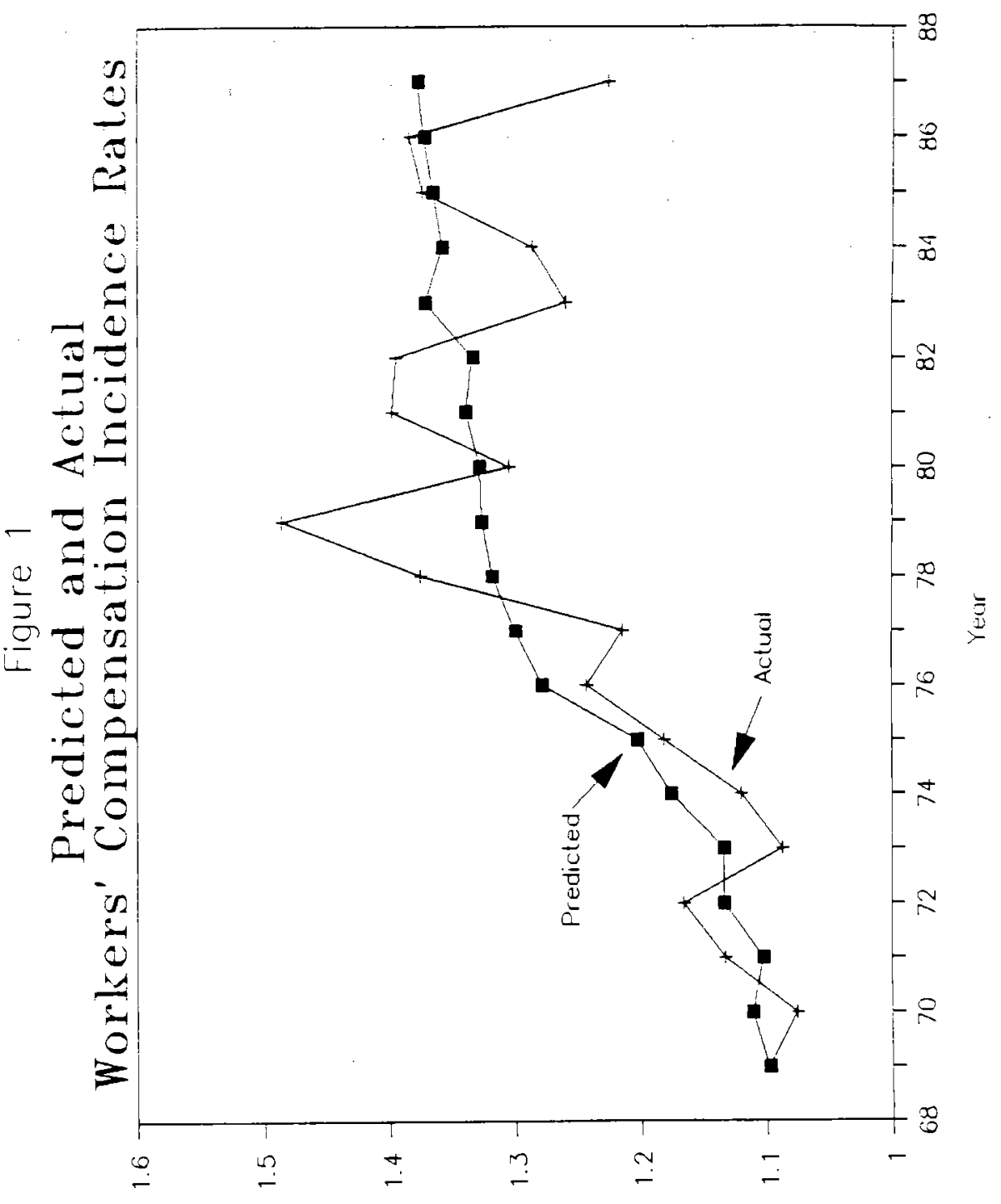

Siayiom OOL dad ajoy asuap!oul 
data, the figure shows that the actual workers' compensation claims rate increased sharply in the 1970 s. The predicted incidence rate tracks the upward trend in the actual incidence rate in the 1970 s reasonably well, but the actual incidence rate is more variable than the predicted incidence rate. The predicted and the actual incidence series deviate somewhat in the late 1970 s, but by the end of the 1980 s the two series are about equal.

Overall, the predicted incidence rate accounts for two-thirds of the variation in the actual incidence rate. Moreover, a test based on the regression of the actual incidence rate on the predicted incidence rate does not reject the hypothesis that the predicted incidence rate is an unbiased estimator of the actual incidence rate. ${ }^{30}$ Although other factors that affect workers' compensation incidence undoubtedly changed in the time period under study, the aggregate prediction of the incidence rate based on the parameters of the cross-sectional model and past benefits provide plausible estimates of the growth in workers' compensation incidence over the last two decades.

${ }^{30}$ In other words, one could not reject that the relationship between the actual and projected incidence rate has a slope of one and a zero intercept. 


\section{Conclusion}

This paper has provided new evidence on the determinants of participation in the workers' compensation insurance program. The main finding is that the micro-level analysis finds a positive relationship between benefits and claims for men but not for women. Overall, a 10 increase in benefits is associated with about a 7 increase in recipiency. The micro-level model is found to provide a plausible prediction of time-series trends in the aggregate workers' compensation incidence rate. The rapid growth of the workers' compensation program in the 1970 s coincided with large real increases in benefits.

There are two potential causes of a positive relationship between claims and benefits, assuming that such a relationship is not spurious. On the one hand, higher benefits may induce workers (or firms) to reduce the level of onthe-job safety and therefore increase the frequency of actual work disabilities. On the other hand, higher benefits may not actually affect the frequency of "true" on-the-job injuries, but may instead induce workers to file fraudulent claims, or to file claims for disabilities that otherwise woul have occurred but would not have been reported without a sufficient monetary incentive. Although more research is clearly needed to disentangle the reporting effect from the moral hazard effect, for some purposes the distinction is unimportant. For example, both causes of a positive association between benefits and recipiency have labor supply consequences, and affect the cost of the program.

Finally, the analysis finds that employees are substantially less likely to enter the workers' compensation program if a state requires a longer waiting period before benefit payments begin. Moreover, this result holds even though benefits are paid retroactively to cover the initial waiting 
period if the disability persists beyond a certain time period. This suggests that an efficient way to insure workers against possible catastrophic economic losses that follow severe, unanticipated work-related disabilities would be to require a relatively long waiting period. The waiting period in every state is currently seven days or less. Extending the waiting period for indemnity benefits to fourteen days would eliminate a great number of claims that entail relatively minor economic losses, but would not deter workers with major disabilities and catastrophic economlc losses from receiving benefits. Moreover, if in some cases disabilities of short duration are determined to cause economic hardship, the program could be amended to provide short-term, low-interest loans to these individuals until they return to work.

It must be stressed, however, that no evidence has been presented here suggesting that it is efficient to delay the provision of medical benefits and rehabilitation services. To the contrary, it is likley to be welfare improving to provide medical care and rehabilitation services as soon as possible after a serious work-related injury has occurred because delay in providing these benefits may aggravate a worker's disability and reduce his motivation to return to work. Priorities in the current workers' compensation insurance system are often reversed. Indemnity benefits are paid-out after a short waiting period, while bureaucratic procedures and mistakes often delay reimbursement for medical care and rehabilitation services for months. 


\section{Appendix}

Derivation of Workers' Compensation Incidence Rates, 1969-87

The time-series of workers" compensation insurance incidence rates used in section 5 is derived from the March Current Population Survey each year from 1970 to 1988 . The Income Supplement portion of the survey contains a question asking whether an individual received any money income from workers' compensation insurance in the preceding calendar year. Responses to this question were used to estimate the annual incidence rate of new claims as follows. First, the sample was restricted to individuals who worked at least one week in the preceding year. ${ }^{31}$ The sample was required to have at least one week of work experience because for a claim to be a new claim, a worker must have worked at least part of the year in which he or she collected benefits. The fraction of workers in a given year who collected workers' compensation insurance was then calculated for calendar years 1969-1987.

Several adjustments to these figures were necessary to derive a consistent new-claims rate series. The first adjustment is necessary because the CPS questionnaire was expanded in 1980 to include a more probing set of income questions. Specifically, beginning in 1980 the survey also included a question on whether survivors received a dependency allowance from workers' compensation, and whether those with disabilities received income from workers' compensation. Fortunately, the impact of the change in the questionnaire can be estimated and taken into account because the 1979 survey administered the old (pre-1980) questionnaire to five of the eight rotation

${ }^{31}$ The sample includes private as well as public sector workers. Workers in the railroad industry, however, were eliminated from the sample because data on coverage do not include railroad workers. 
groups in the sample, and administered the new questionnaire to three of the eight rotation groups. My tabulations show that in 1979 the new questionnaire detected about 20 more workers' compensation recipients than the old questionnaire. This information was then used to scale down the recipiency rate after 1980 to make the survey responses comparable over time.

The second adjustment is necessary because coverage under workers' compensation insurance is incomplete. Using Nelson's (1988a) annual estimates of the fraction of the workforce covered by workers' compensation insurance, the incidence rates were adjusted to reflect incidence per 100 covered workers. Since the fraction of workers covered by workers' compensation in this time period was relatively constant, ranging from .833 to .877 , this adjustment has little effect on the trend in incidence.

A final adjustment is necessary because the number of workers' compensation recipients who work in year $t$ includes a small number of workers who are on spells that began in the previous year (or in earlier years) and that ended in year $t$. These are not new claims. Consequently, it is necessary to adjust for claims that overlap calendar years. The fraction of claims that began in year $t-l$ and were observed in year $t$ was calculated by assuming that there is a uniform distribution of injury starting dates over the year, and that the duration of a claim is independent of the injury starting date. If we let $F(x)$ be the cumulative share of claims lasting $\mathrm{x}$ weeks or less, then under these two mild assumptions the fraction of claims observed in year t that actually are for injuries that began in year $t$ 1 , denoted $\rho$ is

$$
\rho=\frac{(1-F(52))+(1-F(51))+(1-F(50))+\ldots+(1-F(1))}{52}=1-\Sigma F(x) / 52 .
$$


Based on the distribution of claims durations in Minnesota, I estimate $p$ to equal .097. A similar calculation could also be made for claims that began in year $t-2$, $t-3$, etc. But since only a trivial fraction of cases persist beyond one year, claims that overlap two or more calendar years were ignored.

Focusing only on claims that began in the preceding year, these assumptions imply a first-order moving average process for the new-clains rate. Specifically, the observed number of observed ongoing claims in year $t$, $z_{t}$, is

$$
z_{t}=y_{t}+0 y_{t-1}
$$

where $y_{t}$ is the number of claims that originated in year $t$ (i.e., new claims), and $y_{t-1}$ is the number of claims that originated in year t-1. Assuming that $p$ is constant over time, the $\mathrm{MA}(1)$ can be inverted to derive the number of net recipients each year. ${ }^{32}$ The ratio of the number of new recipients to the total number of covered workers is the incidence rate analyzed in section 5 .

${ }^{32}$ To invert a first-order moving average it is necessary know $y$ in at least one year. The $\mathrm{MA}(1)$ process was inverted by assuming that the number of new claims, $y_{t}$, was stationary before 1969. In this situation, $y_{0}=z_{0} /(1-p)$. After $y_{0}$ is estimated, the MA(1) can be solved iteratively. 


\section{REFERENCES}

Bartel, Ann and Lacy G. Thomas, "Direct and Indirect Effects of Regulation: A New Look at OSHA's Impact," Journal of Law and Economics 28, April 1985. pp. $1-25$.

Butler, Richard, "Nage and Injury Response to Shifting Levels of Workers" Compensation," in J. Worrall, ed., Safety and the workforce (I raaca, NY: Cornell University Press, 1983.

Butler, Richard and John Worrall, "Workers' Compensation: Benefit and Injury Claims Rates in the Seventies," Review of Economics and Statistics 60 , November 1983, pp. 580-589.

Butler, Richard and John Worrall, "Work Injury Compensation and the Duration of Nonwork Spells," Economic Journal 95, September 1985, pp. 714-724. Carmichael, Lorne, "Reputations for Safety: Market Performance and PoIicy Remedies," Journal of Labor Economics 4, October 1986, pp. 458-472.

Chelius, James, Workplace Safety and Health: The Role of Workers'

Compensation (Washington, DC: American Enterprise Institute, 1977).

Chelius, James, "The Influence of Workers' Compensation on Safety Incentives," Industrial and Labor Relations Review 35, January 1982, pp. $235-242$.

Chelius, James, "The Incentive to Prevent Injuries," in J. Worrall, ed., Safetv and the Workforce (Ithaca, NY: Cornell University Press, 1983. Chelius, James, and Karen Kavanaugh, "Workers' Compensation and the Level of Occupational Injuries," Journal of Risk and Insurance 55, June 1988, Pp. $315-323$.

Diamond, Peter, "Insurance Theoretic Aspects of Workers' Compensation," in. Alan Blinder and Philip Friedman, eds., National Resources, Uncertainty. and General Equilibrium Systems: Essays in Memorv of Rafael Lusky (Ver York: Academic Press, 1977) pp. 67-89. 
Ehrenberg, Ronald, "Workers" Compensation, Wages, and the Risk of Injury,"

in John F. Burton, Jr., ed., New Perspectives in Workers' Compensation (Ithaca, NY: ILR Press, Cornell University, 1988) pp. $71-96$.

Feenberg, Daniel, and Harvey Rosen, "State Personal Income and Sales Taxes:

1977-1983," in H. Rosen, ed., Studies in State and Local Public Einance

(Chicago: University of Chicago Press, 1986), pp. 135-179.

Hood, Jack, and Benjamin Hardy, Jr., Workers' Compensation and Emplovee

Protection Law (St. Paul, MN: West Publishing Co, , 1984).

Krueger, Alan, and John F. Burton, Jr., "The Employers' Costs of Workers'

Compensation Insurance: Magnitudes, Determinants, and Public Policy,"

unpublished paper, Princeton University, August 1989.

Lanoie, Paul, "Occupational Safety and Health: The Problem of Double Mora:

Hazard," unpublished paper, Laval University, 1988.

Michelbacher, G.F., and Thomas Nial, Workmen's Compensation Insurance (Vew York: McGraw-Hill Book Company, Inc., 1925).

Mitche11, Olivia, "The Relation of Age to Workplace Injuries," Monthly Labor

Review 111, July 1988, pp. 8-13.

Nackley, Jeffrey, Primer on Workers' Compensation (Washington, DC: The Bureau of National Affairs, 1987).

Nelson, William, "Workers' Compensation: Coverage, Benefits, and Costs, 1985" Social Security Bulletin 51 , January $1988 \mathrm{a}, \mathrm{pp} .4 .9$.

Nelson, William, "Workers' Compensation: 1980-84 Benchmark Revisions," Social Security Bulletin 51, July 1988b, pp. 4-21.

Rea, Samuel, "Workmen's Compensation and Occupational Safety under Imperfect Information," American Economic Review 71, March 1981, pp. 80-93.

Root, Norman, "Injuries at Work Are Fewer Among Older Employees," Monthlv Labor Review 104, March 1981, pp. 30-34. 
Ruser, John, "Workers' Compensation Insurance, Experience-Rating, and Occupational Injuries," Rand Journal of Economics 16, winter. 1985, pp. 487-503.

Russel1, Louise, "Pricing Industrial Accidents," in Monroe Berkowitz, ed., Supplemental Studies for the National Commission on State Workmen's Compensation Laws, vol. 3 (Washington, DC: Government Printing Office). Smith, Robert, "Compensating Wage Differentials and Public Policy," Industriä: and Labor Relations Review, April 1979, pp. 339-352.

Smith, Robert, "Mostly on Monday: Is Workers' Compensation Covering Off-TheJob Injuries?" Unpublished paper, Cornell Universicy, 1986.

U.S. Chamber of Commerce, Emplovee Benefirs, 1985 (Washington, D.C.: U.S. Chamber of Commerce, 1986) p. 21.

Viscusi, W. Kip, Employment Hazards: An Investigation of Market Performance (Cambridge, MA: Harvard University Press, 1979).

Viscusi, W, Kip, "Imperfect Job Risk Information and Optimal Workmen's Compensation Benefits," Journal of Public Economics 14, 1980, pp.319-337. Worrall, John and Richard Butler, "Workers' Compensation: Benefits and Duration of Claims," in J. Worrall and D. Appel (eds.), Workers' Compensation Benefits: Adequacy, Equity and Efficiency (Ithaca, NY: ILR Press, 1985).

Worrall, John, Richard Butler, Philip Borba and David Durbin, "E imating the Exit Rate from Workers' Compensation: New Hazard Rate Estimates." unpublished paper, Rutgers University, October 1987. 